\title{
INTERFERÊNCIA ENTRE DUAS FAIXAS MÓVEIS NEOPROTEROZÓICAS: O CASO DAS FAIXAS BRASÍLIA E RIBEIRA NO SUDESTE DO BRASIL
}

\author{
RODRIGO PETERNEL ${ }^{1}$, RUDOLPH ALLARD JOHANNES TROUW ${ }^{1}$ \\ \& RENATA DA SILVA SCHMITT ${ }^{2}$
}

\begin{abstract}
Resumo Na região de Três Corações afloram sucessões metassedimentares neoproterozóicas da Megassequência Andrelândia, gnaisses granulíticos do Maciço Guaxupé e ortognaisses paleoproterozóicos com zircão ígneo de $2.088 \pm 26$ Ma. Nestas rochas estão registradas várias estruturas e associações metamórficas relacionadas a dois eventos colisionais neoproterozóicos que geraram as faixas móveis Brasília e Ribeira. Duas fases deformacionais continuas (DB1 e DB2) e um evento metamórfico de pressão relativamente alta (MB) são vinculados à Faixa Brasília, enquanto outras duas fases deformacionais (DRI e DR2) e um evento metamórfico (MR) de pressão mais baixa relacionam-se com a Faixa Ribeira. Nas fases DB 1 e DB2 diversas nappes sofreram transporte tectônico de topo para ESE a ENE. O evento MB teve início durante DB 1, visto que as isógradas metamórficas que delimitam áreas de metamorfismo de fácies xisto verde médio a fácies anfibolito são truncadas pelas superfícies de empurrão das fases DB1 e DB2. Já as isógradas Kfeldspato-in/muscovita-out e sillimanita-in relacionadas à fácies granulito são concordantes com as superfícies de empurrão DB2, mostrando que o auge do evento MB foi sin-DB2. Durante a fase DR 1 as nappes foram dobradas lateralmente em dobras com plano axial íngreme e eixos caindo para WSW. As isógradas do evento MR truncam as estruturas pré-existentes, mostrando a superimposição deste evento sobre a Faixa Brasília. Por fim, a última fase deformacional registrada (DR2) gerou zonas de cisalhamento transcorrentes dúcteis-rúpteis destrais, com rumo SW-NE, que cortam e deslocam tanto as estruturas e isógradas da Faixa Brasília quanto as da Faixa Ribeira.
\end{abstract}

Palavras-chave: palavras-chave: Zona de interferência, Faixas Móveis Brasília e Ribeira, Geologia estrutural, Metamosrfismo

\begin{abstract}
INTERFERENCE BETWEEN TWO NEOPROTEROZOIC FOLD BELTS: THE EXAMPLE OF THE BRASILIA AND RIBEIRA FOLD BELTS, SOUTHEAST BRAZIL Neoproterozoic metasedimentary successions of the Andrelândia Sequence, gneisses of the Guaxupé Massif and Paleoproterozoic ortogneisses, with igneous zircon of $2.088 \pm 26 \mathrm{Ma}$, constitute the Precambrian units in the Três Corações region, southern Minas Gerais State. Deformational structures and metamorphic associations indicate two collisional events related to the Neoproterozoic orogeny, that originated the Brasília and Ribeira fold belts. Two continuous deformational phases (DB1 and DB2) and a relatively high pressure metamorphic event (MB) were related to the Brasília fold belt. Superposed and related to the Ribeira fold belt, two deformational phases (DR1 and DR2) and a lower pressure metamorphic event (MR) are recognized. DB1 and DB2 produced nappes with movement to ESE, E and ENE. MB metamorphism started during DB1, as indicated by metamorphic isograds that are dislocated by DB1 and DB2 structures. K-feldspar-in/muscovite-out and sillimanite-in isograds related to the granulite fácies are concordant with DB2 thrust faults, showing that the MB peak was sin-DB2. Folds with steep axial planes and axes plunging to WSW were produced during DR I that folded the nappes lateraly. The fact that metamorphic isograds related to the MR metamorphic event cut MB isogrades and pre-existing structures shows the superimposition of this event on the Brasília fold belt evolution. Finally, the last deformational phase DR2 produced dextral transcurrent ductile-brittle shear zones with SW-NE strike, that cut structures and metamorphic isograds of both fold belts.
\end{abstract}

Key-words: Interference zone, Brasília and Ribeira mobile belts, Structural geology, metamorphism

INTRODUÇÃO Na região de Três Corações predominam estruturas e associações metamórficas relacionadas à Faixa Brasília, modificadas pela deformação e metamorfismo superposto, ligado à Faixa Ribeira (Fig. la). Baseado em mapeamento geológicoestrutural de semi-detalhe, interpretação de seções geológicas e análises microtectônica e petrográfica, foi determinada a relação temporal entre diferentes fases deformacionais e eventos metamórficos relacionados à evolução das referidas faixas durante a Orogênese Brasiliana (Almeida \& Hasui, 1984). O objetivo deste estudo é contribuir para o entendimento da evolução tectônica da região e de zonas de interferência/superposição entre faixas móveis em geral.

SÍNTESE SOBRE AS FAIXAS BRASÍLIA E RIBEIRA A Faixa Brasília se estende por mais de $1.000 \mathrm{~km}$ na margem oeste do Cráton do São Francisco (Fig lb), dividida pela mega-inflexão dos Pirineus em dois segmentos: norte e sul. No segmento sul ocorrem, de W para E, três zonas: interna, externa e cratônica (Marini et al., 1984; Fuck et al., 1994), com registro de dois eventos colisionais. O primeiro está representado por granodioritos e granitos sin a tardi-tectônicos, com idade de cristalização em torno de 794 Ma (U-Pb em zircão; Pimentel et al., 1992). O segundo evento, entre 630-610 Ma (Dardenne, 2000), gerou empurrões para SE, granitogênese e metamorfismo com gradiente aumentando de E para W, atingindo fácies anfibolito alto e, localmente, granulito na zona interna.

Na região da Nappe de Passos Valeriano et al. (1993) e Simões (1995) reconheceram quatro fases deformacionais (D1 a D4) e um evento metamórfico, associados ao segundo evento colisional. As fases contínuas D1 e D2 desenvolveram foliações de baixo ângulo e lineações variando entre E-W e NW, relacionadas com o transporte para SE que culminou com a exumação e colocação da

I - Departamento de Geologia -UFRJ Av. Brigadeiro Trompowski s/nº, CCMN bl. G Ilha do Fundão, Rio de Janeiro, RJ, CEP: $21949-900$ (rpeternel@uol.com.br; rajtrouw@hotmail.com)

2 - Departamento de Geologia Regional e Geotectônica da FGEL-UERJ, rua São Francisco Xavier 524/4024^, Maracanã, Rio de Janeiro, RJ, CEP 205590)13(renataschmitt@uol.com.br) 
Nappe de Passos, ou domínio interno, sobre o domínio externo. A fase D3 gerou dobras abertas com plano axial subvertical e eixo com caimento suave para NW ou SE e falhas transcorrentes subverticais NW-SE com movimentação horizontal sinistral. A fase D4 gerou dobras abertas com com plano axial subvertical e eixo com caimento suave para SSW ou NNE. O evento metamórfico, com auge cedo-sin-D2, apresenta gradiente inverso, com fácies xisto verde médio na base e fácies anfibolito superior no topo da Nappe de Passos e isógradas metamórficas com contornos aproximadamente paralelos ao acamamento e à superfície de empurrão basal da nappe. Cianita como aluminossilicato estável até facies anfibolito alto em rochas metassedimentares indica pressão relativamente alta.

A continuidade da Faixa Brasília ao sul da região da Nappe de Passos onde suas características são gradualmente mascaradas pela superposição de eventos ligados à Faixa Ribeira é sugerida por Trouw et al (1994), Ribeiro et al (1995), Campos Neto \& Caby (1999), Valeriano (1999) e Heilbron et al (2000).

A Faixa Ribeira estende-se no rumo NE-SW por cerca de $1.400 \mathrm{~km}$ transicionando a nordeste para a Faixa Araçuaí (Fig 1). Sua evolução está ligada a subducção para SE da paleoplaca Sanfranciscana e posterior colisão desta com a microplaca da Serra do Mar e o paleocontinente do Congo durante a Orogênese Brasiliana (Heilbron et al. 2000). Neste trabalho será enfocado o segmento central da Faixa Ribeira, subdividido por Heilbron et al. (2000) em quatro terrenos tectono-estratigráficos principais (Tabela 1) com registro de dois episódios colisionais. Segundo esses autores, o primeiro episódio divide-se em quatro estágios tectônicos: 1) Pré-colisional - 630 a $595 \mathrm{Ma}$ - subducção para SE da paleoplaca Sanfranciscana sob a Microplaca da Serra do Mar (Campos Neto \& Figueiredo 1995), gerando plútons granitóides do Arco Magmático Rio Negro (Tupinambá et al. 1998); 2) Colisional - 595 a $565 \mathrm{Ma}$ - colisão oblíqua entre as paleoplacas supracitadas, gerando superfícies de empurrão com transporte para NW registrado em duas fases deformacionais contínuas (DR I e DR2); primeiro evento metamórfico (MRI), cedo sin-colisional, de pressão intermediária, com gradiente inverso aumentando para SE, de fácies xisto verde superior a fácies anfibolito superior; geração de plutons granitóides tipo $\mathrm{S}$ associados às superfícies de empurrão; 3) Tardi-colisional - 565 a 540 Ma - geração de plutons graníticos, predominantemente de tipo I, fracamente foliados (ex. batólito da Serra dos Órgãos); 4) Pós-colisional - 540 a $520 \mathrm{Ma}$ - fase compressiva (DR3), aproximadamente SE-NW, com geração de dobras com planos axiais subverticais

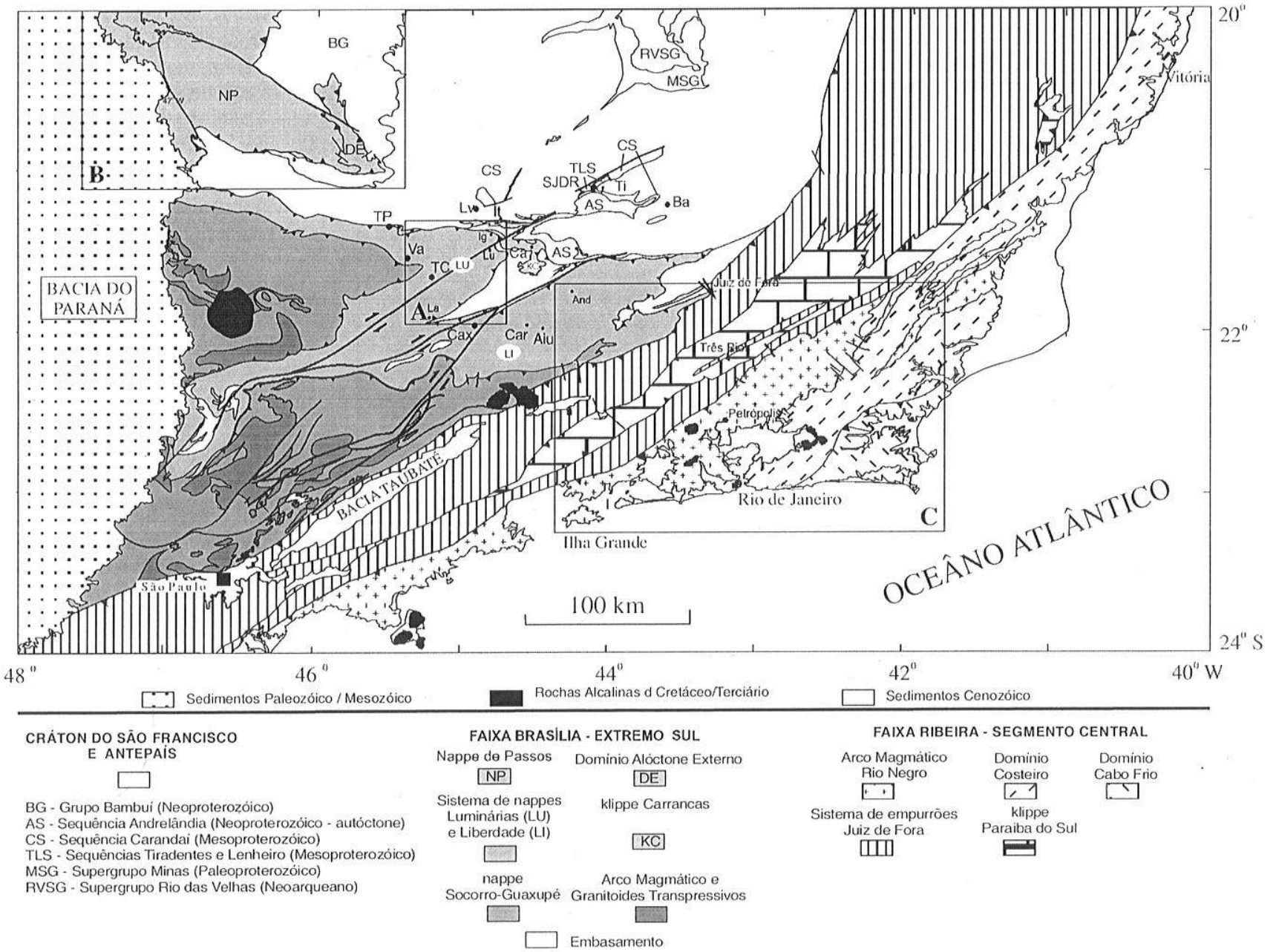

Figura 1 - a) Mapa geológico simplificado da região sudeste do Brasil, com a localização de: A) área do presente trabalho; B) extremidade sul da Faixa Brasília, C) Segmento central da Faixa Ribeira (modificado de Trouw et al, 2000). 
Tabela 1 - Principais unidades tectono-estratigráficas do segmento central da Faixa Ribeira e suas subdivisões (modificado de Heilbron et al. 2000 ).

\begin{tabular}{|c|c|c|c|}
\hline $\begin{array}{l}\text { Terrenos } \\
\text { Principais }\end{array}$ & $\begin{array}{c}\text { Unidades } \\
\text { Tectôno-Estratigráficas }\end{array}$ & Unidades Litológicas & Idades \\
\hline \multirow{4}{*}{ Terreno } & \multirow{4}{*}{$\begin{array}{l}\text { Domínio } \\
\text { Andrelândia }\end{array}$} & Granitóides sin-tardi colisionais & Neoproterozóico \\
\hline & & Seqüência Andrelândia & Neoproterozóico \\
\hline & & Complexo Mantiqueira & Arqueano/ \\
\hline & & & Paleoproterozóico \\
\hline \multirow[t]{3}{*}{ Ocidental } & \multirow{3}{*}{$\begin{array}{l}\text { Domínio } \\
\text { Juiz } \\
\text { de Fora }\end{array}$} & Granitóides sin-tardi colisionais & Neoproterozóico \\
\hline & & Sequência Andrelândia & Neoproterozóico \\
\hline & & Complexo Juiz de Fora & Paleoproterozóico \\
\hline \multirow{3}{*}{$\begin{array}{l}\text { Klippe } \\
\text { Paraíba } \\
\text { do Sul }\end{array}$} & \multirow{3}{*}{-} & Granitóides sin-tardi colisionais & Neoproterozóico \\
\hline & & Grupo Paraíba do Sul ( Sequência Andrelândia) & $(?)$ \\
\hline & & Complexo Quirino & Paleoproterozóico \\
\hline \multirow{3}{*}{$\begin{array}{l}\text { Terreno } \\
\text { Oriental }\end{array}$} & \multirow{3}{*}{$\begin{array}{l}\text { ( = Domínio } \\
\text { Costeiro) }\end{array}$} & Granitóides sin-tardi colisionais & Neoproterozóico \\
\hline & & Sequência Italva & Neoproterozóico \\
\hline & & Arco Magmático Rio Negro & Neoproterozóico \\
\hline \multirow{3}{*}{$\begin{array}{l}\text { Terreno } \\
\text { Cabo } \\
\text { Frio }\end{array}$} & \multirow{3}{*}{$\begin{array}{l}\text { (= Domínio Tectônico } \\
\text { Cabo Frio, } \\
\text { Schmitt, 2001) }\end{array}$} & Leucogranitos & Neoproterozóico \\
\hline & & Sucessão Búzios-Palmital & Neoproterozóico \\
\hline & & Complexo Região dos Lagos & Paleoproterozóico \\
\hline
\end{tabular}

(megassinforma Paraíba do Sul e megantiforma Rio de Janeiro) e zonas de cisalhamento dúcteis destrais com rumo NE-SW (Zona de Cisalhamento Paraíba do Sul). Ainda é reconhecida compressão regional final E-W (Trouw et al. 2000) responsável por uma quarta fase deformacional (DR4), que gerou dobras abertas a apertadas com eixos N-S e plano axial subvertical, além de zonas de cisalhamento destrais com rumo NE-SW bem desenvolvidas no domínio autóctone e zonas de cisalhamento sinistrais, mais discretas, com rumo NW-SE, observadas em todos os domínios.

O segundo epísódio, entre 525 e $490 \mathrm{Ma}$ (Schmitt 2001) resultou da colisão entre o terreno oriental e o Domínio Tectônico Cabo Frio (DTCF), no qual a autora supracitada reconheceu cinco fases deformacionais, em parte correlacionavéis temporalmente às fases de Heilbron et al. (2000) e um evento metamórfico de pressão relativamente alta na transição das fácies anfibolito e granulito.

GEOLOGIA REGIONAL Na região ao sul da borda meridional do Cráton do São Francisco (CSF) importante discordância regional, ora litológica, ora angular, separa embasamento Paleoproterozóico/Arqueano, composto por terrenos ortognáissicos e faixas tipo granito-greenstone, de sucessões metassedimentares Mesoproterozóicas das sequiências São João Del Rei, Tiradentes e Carandaí, e Neoproterozóicas da Megassequiência Andrelândia (Paciullo et al, 2003; Fig.2).

Segundo Paciullo et al, (2003) a Megasseqüência Andrelândia (MSA) é composta, da base para o topo, por seis associações de litofácies: AL1: biotita gnaisses finos bandados com intercalações de anfibolitos; AL2: biotita gnaisses finos bandados com intercalações de quartzitos, xistos e anfibolitos; AL3: quartzitos com xistos e escassos conglomerados intercalados; AL4: filitos/ xistos cinzentos com intercalações quartzíticas subordinadas; AL5: biotita xistos/gnaisses finos, maciços ou laminados, localmente com grânulos e seixos pingados; AL6: biotita xistos/gnaisses grossos, com intercalações de rochas calcissilicáticas, "gonditos", quartzitos e anfibolitos. Uma discordância interna separa a MSA' em Sequiência Carrancas, composta pelas associações ALl a AL4, e Sequiência Serra do Turvo composta pela associação AL5. Estas associações gradam lateralmente para a associação AL6 que representa sucessões distais da bacia, depositadas contemporaneamente às outras associações.
As sucessões da MSA e rochas do seu embasamento apresentando um complexo padrão tectôno-metamórfico, com registro de distintas fases deformacionais e associações metamórficas relacionadas ao desenvolvimento das faixas Brasília e Ribeira durante a Orogênese Brasiliana.

Ribeiro et al. (1995) descreveram quatro fases de deformação regional, $D_{B 1}$ e $D_{B 2}$ relaconados a Faixa Brasília e $D_{R 1}$ e $D_{R 2}$ a Faixa Ribeira.Nas duas primeiras fases o transporte tectônico foi para SE e ENE, respectivamente, durante deformação compressiva contínua, associada ao processo colisional responsável pelo fechamento da Bacia Andrelândia. Na fase $D_{R 1}$ ocorreu transporte tectônico para NW enquanto na fase $D_{R 2}$ uma compressão $E-W$ tardia gerou zonas de cisalhamento subverticais destrais com rumo NE-SW.

Três domínios tectônicos pré-cambrianos (Fig.2) foram identificados (Ribeiro et al. 1990):

domínio autóctone - transição do antepaís do Cráton do São Francisco para porção autóctone da zona orogênica, com a deformação aumentando de norte para sul, para o interior da zona orogênica;

domínio alóctone II - predomina sucessão de nappes e escamas empurradas, apresentando, em geral, transporte tectônico de topo para ENE e intensa deformação dúctil, associadas a indentação da Nappe Guaxupé, relacionada à evolução da Faixa Brasília. Estruturas relacionadas à Faixa Ribeira, como zonas de cisalhamento destrais subverticais SW-NE e dobras abertas assimétricas com plano axial subvertical e eixos com caimento para SW-NE e N-S estão localmente superpostas às estruturas da Faixa Brasília;

domínio alóctone III - zona de interferência mais intensa entre as faixas Brasília e Ribeira. A nappe Liberdade sintetiza o padrão tectônico deste domínio, com indicadores cinemáticos registrando transporte tectônico original para NE, relacionado à evolução da Faixa Brasília, sobreposto por outros com transporte para NW, relacionado à Faixa Ribeira. Ressaltam-se ainda importantes zonas de cisalhamento destrais subverticais SW-NE, relacionadas à estruturação tardia da Faixa Ribeira. Trouw et al. (1994) interpretam o domínio II como continuidade meridional da Faixa Brasília e o domínio III como zona de interferência entre as faixas Brasília e Ribeira. 

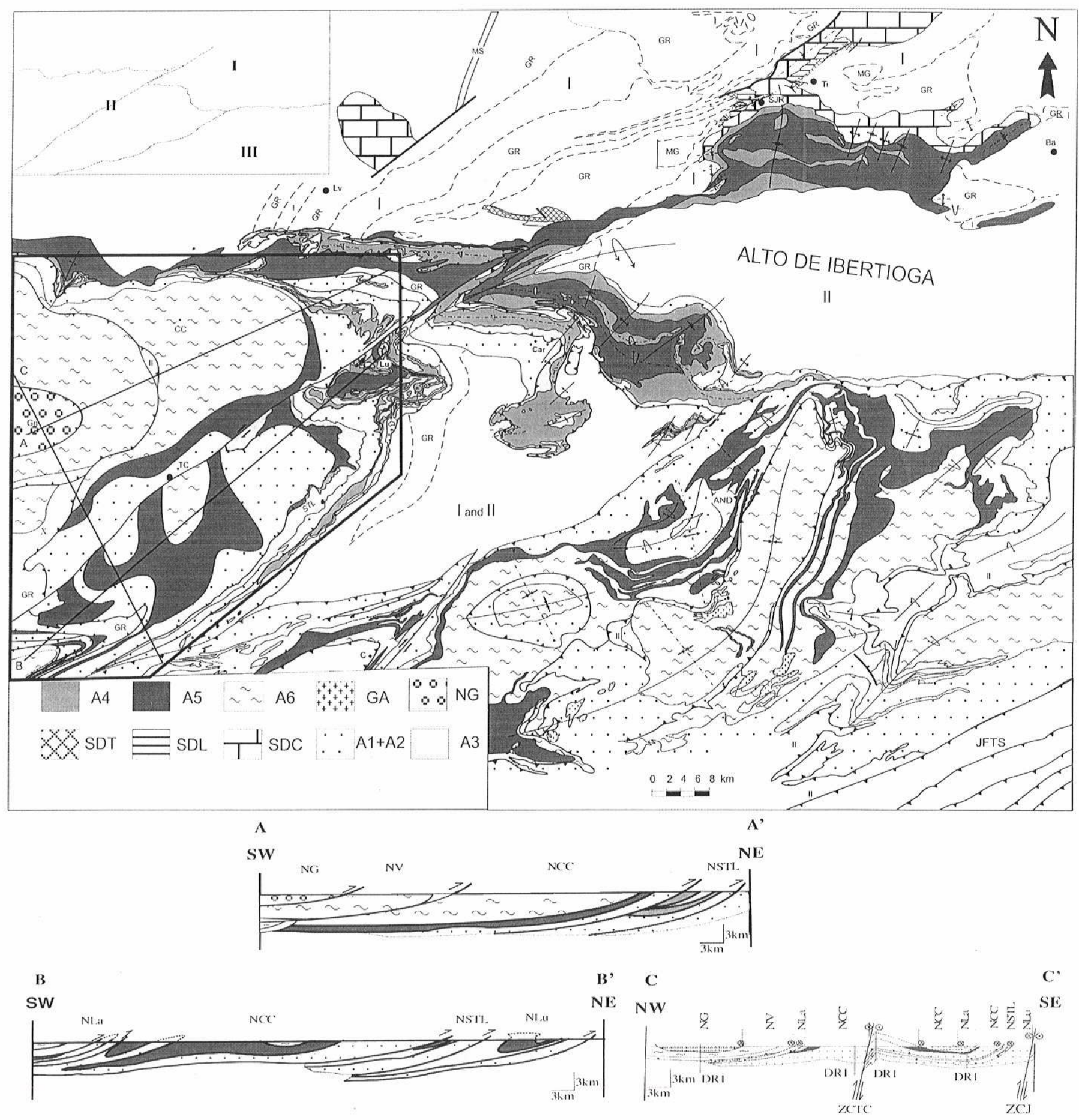

Figura 2 - a) Mapa geológico da zona de interferência entre as faixas móveis Brasília e Ribeira, no sul de Minas Gerais. Embasamento: I) greenstone belts, II) Ortognaisses Paleoproterozóico/Arqueano, MS) Supergrupo Minas; Intrusões Paleoproterozóicas: GR) granitóides, $M G$ ) gabróicas. Sequências Deposicionais Proterozóicas: SDT) Tiradentes, SDL) Lenheiro, SDC) Carandaí, MSA) Andrelândia, Unidades da MSA: AL1 e AL2) biotita gnaisses bandados, com intercalações de quartzitos, anfibolitos e xistos máficos I ultramáficos, AL3) quartzitos com intercalações de muscovita-xistos, ALA) filitos / xistos cinzentos com intercalações quartzíticas subordinadas, AL5) biotita-xistos, maciços ou laminados, localmente com grânulos e seixos pingados, AL6) biotita-xistos / gnaisses grossos, com intercalações de anfibolitos, quartzitos, metacherts e rochas calcissilicáticas. Áreas pretas) principais corpos ultramáficos; GA) granitos anatéticos, NG) Nappe Guaxupé, JTFS) Sistema de empurrões Juiz de Fora. Cidades: SJR-São João Del Rei, Ti-Tiradentes, Ba-Barbacena, Lv-Lavras, Car-Carrancas, Lu-Luminárias, Cc-Carmo da Cachoeira, Tc-Três Corações, CCaxambu, AND-Andrelândia, BJM-Bom Jardim de Minas. Detalhe na parte superior esquerda: Domínios Tectônicos - I) autóctone, II eIII) alóctones. Polígono Preto - área do presente trabalho, A, B e C-Seções geológicas. b) Seções geológicas A-A', B-B' e C-C',. modificado de Paciullo (1997), Peternel (2000) e Trouw et al (2000). 
Dois eventos metamórficos foram reconhecidos (Trouw \& Oliveira Castro 1996, Ribeiro et al. 1995). O primeiro, $M_{1}$, relacionado à evolução da Faixa Brasília, de pressão relativamente alta, gerou metamorfismo de facies xisto verde na parte autóctone até granulitos com cianita e K-feldspato na Nappe Varginha. O segundo, $M_{R}$ caracterizado por sillimanita fibrosa em metapelitos nos domínios II e III, e cordierita no domínio III, foi vinculado à Faixa Ribeira. O surgimento de sillimanita prismática em granulitos do topo da nappe Varginha, estrutura da fase DB2, é correlacionado ao metamorfismo da Faixa Brasília (Campos Neto \& Caby 1999, Peternel 2000).

Segundo Ribeiro et al. (1990) o evento $M_{B}$ é contemporâneo às fases deformacionais $D_{B 1}$ e $D_{B 2}$ e o evento $M_{R}$ às fases $D_{R 1} e$ $\mathrm{D}_{\mathrm{R} 2}$. O evento MB teria idade mínima em torno de $604 \pm 16 \mathrm{Ma}$ (isócrona $\mathrm{Sm}-\mathrm{Nd}$, granada $\mathrm{x}$ rocha total em retro-eclogitos da MSA, Trouw \& Pankhurst 1993) e o evento MR idade de 567 11 Ma (U$\mathrm{Pb}$ em zircão de quartzo-xisto da MSA, Söllner \& Trouw 1997). Machado et al. (1996) apresentaram idades U-Pb em zircões de rochas do segmento central da FR, que confirmam a existência de pelo menos dois pulsos tectono-metamórficos distintos relacionados ao Evento Termo-tectônico Brasiliano ao sul do Cráton do São Francisco.

\section{GEOLOGIA DA REGIÃO DE TRÊS CORAÇÕES E ADJACÊNCIAS Unidades litológicas EMBASAMENTO} É domínio autóctone e ocorre em fatias tectônicas na base de nappes, alcançando centenas de metros de espessura. A parte alóctone é constituída somente de ortognaisses graníticos a granodioríticos, com feições migmatíticas (estruturas oftálmica e estromática). No domínio autóctone ocorrem, além destes ortognaisses migmatíticos, corpos meta-ultramáficos (tremolitaactinolita xisto e talco xisto) e subordinadamente hornblenda-biotita gnaisse, granada-biotita gnaisse, anfibolitos, xistos máficos, rochas calcissilicáticas, quartzito ferruginoso e "gonditos" (Bittar 1989, Almeida 1992). As lascas alóctones do embasamento apresentam elementos estruturais paralelos às estruturas presentes nas rochas supracrustais. A datação de zircão (método U-Pb) de amostra desta área confirmou que os ortognaisses graníticos alóctones constituem embasamento das sucessões Neoproterozócas da Megassequiência Andrelândia (ver adiante).

ORTOGNAISSES DA NAPPE GUAXUPÉ A oeste da cidade de Varginha ocorrem ortognaisses granulíticos de composição charnoquítica a enderbítica, com bandamento composicional definido por bandas, relativamente contínuas, milimétricas a centimétricas, leucocráticas, de composição quartzo-feldspática, e melanocráticas, ricas em piroxênios e anfibólio. A associação mineralógica característica é plagiclásio, microclina, quartzo, diopsídio, hiperstênio e porcentagens menores de granada, hornblenda, biotita e minerais opacos, além de traços de apatita e zircão.

MEGASSEQÛUENCIA ANDRELÂNDIA (MSA) As associações de litofácies identificadas assemelham-se às descritas por Paciullo et al. (2000; 2003), porém não foi possível individualizar as duas primeiras associações.

AL1+AL2: Biotita gnaisse Associação de litofácies basal, posicionada discordantemente sobre ortognaisses do embasamento ou tectonicamente, através de falhas de empurrão, sobre rochas de outras associações da MSA. É constituída principalmente por biotita gnaisses de granulometria fina com estratificação delgada, lateralmente contínua, definida pela alternância de camadas quartzo-feldspáticas mais ou menos ricas em biotita. Algumas camadas quartzo-feldspáticas são um pouco mais espessas e apresentam granulometria média a grossa, localmente com grânulos e seixos finos arredondados. Ocorrem intercalações de: a) quartzitos, dispostos em sucessões com espessuras decimétrica a métrica, constituídas pelo empilhamento de camadas aparentemente tabulares, delgadas a médias, separadas por lâminas micáceas; b) muscovita-quartzo xistos, intercalados nos quartzitos, formando lâminas ou camadas delgadas, isoladas ou agrupadas em sucessões com até 1,5 m de espessura; c) granada quartzito (metachert), geralmente encontrado como blocos soltos, angulosos, com até $30 \mathrm{~cm}$ de espessura; d) tremolita xistos, em camadas de espessura decimétrica e geometria aparentemente tabular, isoladas no gnaisse bandado ou separando este das sucessões quartzíticas; e) escassos xistos carbonáticos e mármores em camadas maciças, delgadas a médias, aparentemente tabulares, intercaladas nos muscovita-quartzo xistos; f) anfibolitos, em camadas delgadas até muito espessas $(\leq 3 \mathrm{~m})$, de geometria aparente tabular:

AL3: Quartzitos Esta unidade assenta-se concordantemente sobre os biotita gnaisses, sendo composta por sucessões quartzíticas e intercalações subordinadas de quartzo-muscovita xistos. Os quartzitos formam camadas delgadas a espessas ( $1 \mathrm{~m})$, de geometria aparentemente tabular ou lenticular muito estendida, geralmente separadas por peliculas micáceas. Os muscovita xistos ocorrem em lâminas ou camadas delgadas isoladas ou agrupadas em monótonas sucessões com até $4 \mathrm{~m}$ de espessura, mais freqüentes na base e no topo da unidade.

ALA: Filitos/xistos cinzentos Composta por sucessões de filitos e xistos cinzentos, de espessura até decamétrica, que lateral e verticalmente gradam para os quartzitos (AL3).

AL5: Biotitaxistos/gnaisses Composta exclusivamente por biotita xistos/gnaisses, finos a médios, homogêneos, formando monótonas sucessões, com até centenas de metros de espessura, geralmente sem estratificação visível. São encontrados estratos de espessura até métrica, compostos pela alternância de camadas tabulares delgadas de biotita xistos laminados e maciços. Localmente, contêm fragmentos detríticos espalhados, de tamanho areia até seixo fino, de plagioclásio, rochas plutônicas quartzofeldspáticas e quartzo de veio. O contato basal é uma paleosuperfície erosiva que pode ser interpretada como uma discordância intraformacional, observada a oeste da Serra de São Tomé, onde biotita xistos (AL5) truncam muscovita xistos (AL4) e quartzitos (AL3), ou pelo posicionamento estratigráfico desta associação sobre todas as associaçõs sotopostas.

AL6: Biotita-muscovita xistos/gnaisses Sucessões de xistos e gnaisses estratificados de granulometria grossa e espessura até decamétrica, separadas por intercalações de quartzitos, rochas calcissilicáticas e anfibolitos, com formas tabulares ou lenticulares estendidas. Ocorrem estratigraficamente sobre os biotita xistos (AL5) com contato gradacional, ou repousam diretamente sobre os ortognaisses do embasamento através de contato brusco

Evolução termo-tectônica brasiliana Na região de Três Corações são identificadas estruturas relacionadas a quatro fases 
deformacionais, $\mathrm{D}_{\mathrm{B} 1}, \mathrm{D}_{\mathrm{B} 2}, \mathrm{D}_{\mathrm{R} 1}$ e $\mathrm{D}_{\mathrm{R} 2}$ e associações minerais de dois eventos metamórficos, $\mathrm{M}_{13}$ e $\mathrm{M}_{\mathrm{R}}$.

FASE DEFORMACIONAL DBI As estruturas desta fase são quase completamente mascarada pela fase $\mathrm{D}_{132}$, entretanto através de análise microtectônica foi possível encontrar relíctos de estruturas desta primeira fase. Uma foliação $S_{h 1}$ está preservada como trilhas de inclusões orientadas em cristais de granada, crescidas durante o metamorfismo $\mathrm{M}_{\mathrm{B}}$. Estas trilhas fazem ângulos de $40^{\circ}$ a $80^{\circ}$ com a foliação principal $S_{b 2}$ e/ou estão dobradas (Fig. $3 \mathrm{a})$, indicando que existiram duas superfícies de clivagem e xistosidade distintas, porém contínuas, e que a foliação $S_{b 2}$ foi gerada através do dobramento da foliação $S_{b 1}$.

A nordeste da área mapeada (Figs. 2 e 4), encontra-se a Klippe Carrancas, composta por sucessões da MSA, colocada tectonicamente sobre domínio autóctone. Paciullo (1997) identificou superfícies de empurrão, foliações $\left(\mathrm{S}_{\mathrm{bl}}\right)$ e lineações $\left(\mathrm{L}_{\mathrm{b} 1}\right)$, que indicam movimento tectônico de topo para ESE, responsável pela formação da klippe durante a fase $\mathrm{D}_{\mathrm{B} 1}$.

FASE DEFORMACIONALDB2 Desenvolveu sistema de nappes com transporte tectônico de topo para ENE, estruturado em sinformal aberto, com eixo de baixo caimento para WSW, constituído por sucessões da MSA e ortognaisses do seu embasamento. São identificadas cinco nappes, da base para o topo: Luminárias, São Tomé das Letras, Carmo da Cachoeira, Lambari e Varginha. No topo do empilhamento aparecem granulitos da base da Nappe Guaxupé (Fig. 4). O desenvolvimento deste sistema de nappes causou o dobramento da Klippe Carrancas em sinformal fechado com eixo variando de E-W a SE-NW. Truncamento de isógradas e descontinuidades no padrão metamórfico, superposição e truncamento de contatos litológicos produzindo repetições estratigráficas e fatias de embasamento entre sucessões da MSA permitiram estabelecer os limites das nappes. Rochas miloníticas ao longo de superfícies de empurrão são escassas devido à recristalização tardi a pós-tectônica. Dobras, abertas até isoclinais, de escala megascópica, associadas com os empurrões, evidenciam o caráter dúctil da deformação. Durante a fase $\mathrm{D}_{\mathrm{B} 2}$ desenvolveram-se a foliação principal $\left(\mathrm{S}_{\mathrm{b} 2}\right)$, lineações de estiramento e mineral $\left(\mathrm{L}_{\mathrm{b} 2}\right)$ e dobras fechadas a isoclinais nas rochas envolvidas no sistema de nappes.

A foliação principal $\left(\mathrm{S}_{\mathrm{h} 2}\right)$ é uma xistosidade contínua, espaçada ou anastomosada, dependendo da rocha na qual se desenvolve, definida pela orientação preferencial de micas, cianita, sillimanita, anfibólio, piroxênios, quartzo e estaurolita. Em geral é subparalela ao acamamento e ao bandamento composicional das rochas, entretanto, aonde $\mathrm{S}_{\mathrm{b} 1}$ ainda é reconhecível $\mathrm{S}_{\mathrm{b} 2}$ apresenta-se como clivagem de crenulação.

A lineação mineral $\left(\mathrm{L}_{\mathrm{b} 2}\right)$ é bem evidente nas rochas xistosas e a lineação de estiramento nos gnaisses, quartzitos e veios de quartzo nos biotita xistos. Ambas apresentam constância na direção, com caimento suave para SW, com atitude média 248/14 (total de 100 medidas), embora se observe lineações $\mathrm{L}_{\mathrm{b} 2}$ com caimento suave para NE, devido ao dobramento posterior: No topo da Nappe Varginha $\mathrm{L}_{\mathrm{b} 2}$ se dispõe em leque, com direções aproximadamente ortogonais ao contato basal da Nappe Guaxupé (Fig. 4), sendo esta distribuição provavelmente relacionada com o posicionamento desta nappe sobre as demais.

As dobras $D_{132}$ são assimétricas, fechadas a isoclinais, com plano axial de baixo mergulho, subparalelo à foliação principal e eixos com caimento suave geralmente ortogonais à direção geral de $\mathrm{L}_{\mathrm{b} 2}$ (Fig.3b). Porém também apresentam direção paralela a $\mathrm{L}_{\mathrm{b} 2}$, podendo ser interpretadas como dobras obliquas (oblique folds, Passchier, 1986).

Os melhores indicadores cinemáticos são bandas de cisalhamento do tipo S-C', estruturas do tipo fish de muscovita, cianita e piroxênio (Fig. 3c), foliation fish de muscovita e lentes de quartzo estirado (Fig. 3d), que indicam transporte tectônico com movimento de topo para ENE, com sentido médio para $60^{\circ} \mathrm{NE}$ (Fig. 4)

FASE DEFORMACIONALDRI Resulta de compressão NW-SE, gerando desde crenulações (Fig. 3e) até dobras de escala regional, geralmente abertas, com traço de planos axiais NE-SW e eixos de caimento suave para WSW. Estas dobras apresentam suave assimetria, com vergência para NW. Este dobramento é coaxial à $\mathrm{D}_{132}$, diferenciando-se pelo estilo das dobras e pela orientação íngreme das superfícies axiais, ortogonais à foliação $S_{\mathrm{b} 2}$. A foliação relacionada a esta fase é de expressão local, representada por planos de clivagem em xistos onde $\mathrm{S}_{\mathrm{b} 2}$ está crenulada.

FASE DEFORMACIONAL DR2 Desenvolveu-se durante compressão E-W, gerando dobras abertas com plano axial vertical e eixo N-S e zonas de cisalhamento subverticais destrais com direção NE-SW (Figs. 2 e 4). Estas dobras e todas as estruturas pré-existentes são truncadas e deslocadas pelas zonas de cisalhamento. Na área em questão ocorrem as zonas de cisalhamento de Jesuânia (ZCJ) e Três Corações (ZCTC). Ao longo destas zonas ocorrem milonitos e cataclasitos que registram comportamento reológico dúctil-rúptil das rochas envolvidas. Os planos miloníticos $\left(\mathrm{S}_{12}\right)$ têm mergulho íngreme a subvertical para $\mathrm{SE}$, contendo lineação de estiramento $\left(\mathrm{L}_{12}\right)$ com atitude média $062 /$ 02 (total de 10 medidas). O principal componente de movimento nestas zonas de cisalhamento é horizontal destral, verificado tanto por indicadores cinemáticos do tipo bandas de cisalhamento S-C' (Fig. 3f), quanto pelo padrão de deslocamento e deflexão das estruturas pré-existentes. Componente de movimento vertical secundário, indicando o levantamento do bloco norte em relação ao bloco sul, pôde ser verificado próximo à cidade de Três Corações, onde ocorre sinformal do início da fase DR2, com xistos da associação AL6 em seu núcleo. No bloco sul estes xistos estão em contato com a ZCTC, enquanto que no bloco norte xistos da associação sotoposta AL5, encontram-se em contato com a zona de cisalhamento (Fig. 2). Utilizando-se estruturas lineares e contatos entre unidades de mapeamento truncados pela ZCTC pôde-se estimar deslocamento horizontal em torno de $12 \mathrm{~km}$ e deslocamento vertical da ordem de centenas de metros.

PRIMEIRO EVENTO METAMÓRFICO $\left(M_{B}\right)$ Relacionado à evolução da Faixa Brasília, apresenta associações minerais que indicam condições de pressão mais altas que no metamorfismo barroviano clássico (Tabela 2a). O metamorfismo aumenta de E para $\mathrm{W}$, de fácies xisto verde médio, no domínio autóctone, até fácies granulito, na nappe Varginha. Na Tabela 2 b são indicadas as prováveis reações de surgimento dos minerais que marcam as diferentes fácies metamórficas desenvolvidas no evento MB. Nos granulitos da base da nappe Varginha, cianita permanece como o aluminossilicato estável caracterizando associação mineral de pressão alta, também evidenciada pela presença de rutilo junto com granada ( 70\%Alm, R. Trouw dados inéditos). A presença de sillimanita no topo da Nappe Varginha pode ser interpretada como resultado de aumento de temperatura, consumindo muscovita (8) 

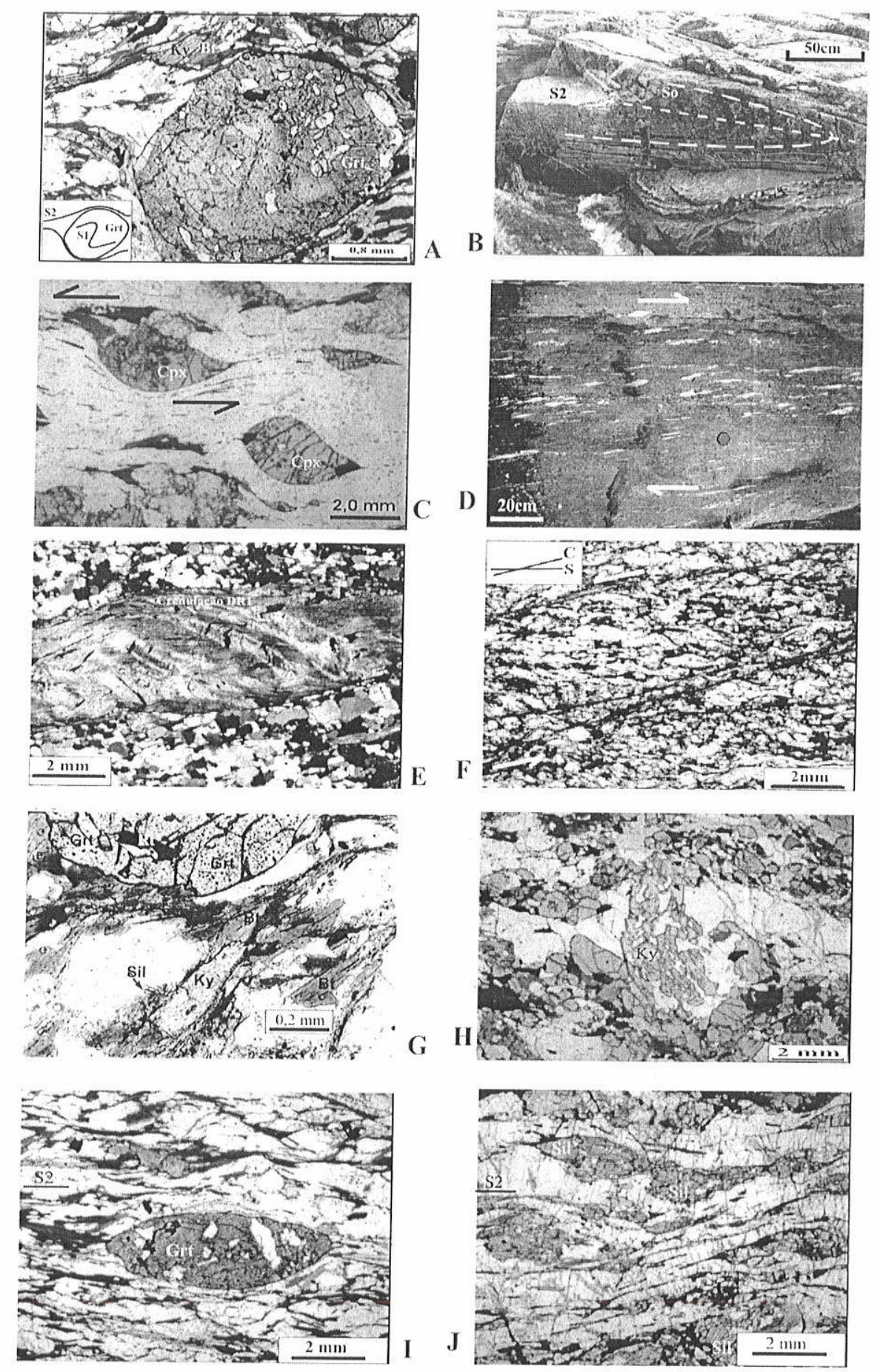

Figura 3 - A) inclusões alinhadas em granada (Grt), em forma de dobra, registrando o dobramento da foliação pretérita $\left(D_{B 1}\right)$, em biotita xisto (ALS); B) dobra $D_{B_{2}}$ fechada, quase isoclinal, em quartzito (AL3), na serra de São Tomé; Indicadores cinemáticos da fase $D_{B 2}:$ C) estrutura tipo fish de clinopiroxênio em granulitos (AL6), indicando movimento destral em mapa; D) biotita xisto (ALS) com veios de quartzo estirados paralelo a foliação $S_{b 2,}$, indicando movimento de topo para NE; E) camada metapelítica intercalada em quartzito (AL3), mostrando a foliação $S_{b 2}$ crenulada durante a fase $D_{R 1} ; F$ ) estrutura tipo $S$-C mostrando movimento sinistral na figura e no mapa topo para $N E$, biotita xisto (ALS) milonítico da fase $D_{R 2}$; G) fibrolita (Sil) crescida durante o evento $M_{R}$ bordejando cianita (Ky) desenvolvida no evento $M_{n, 2}$ em biotita xisto (AL5) - foto de Oliveira Castro (1997); H) cianita (Ky) orientada perpendicularmente à foliação $S_{b 2}$ definida por biotita e fitas de quartzo, em granulitos (AL6) na base da nappe Varginha; I) granada (Grt) com forma elipsoidal e eixo maior orientado em pequeno ângulo com a foliação $S_{b_{2}}$ definida pela orientação preferencial de biotita; J) sillimanita (Sil) prismática com orientação preferencial paralela à foliação $S_{b 2}$ em granulitos (AL5), no topo da nappe Varginha. 


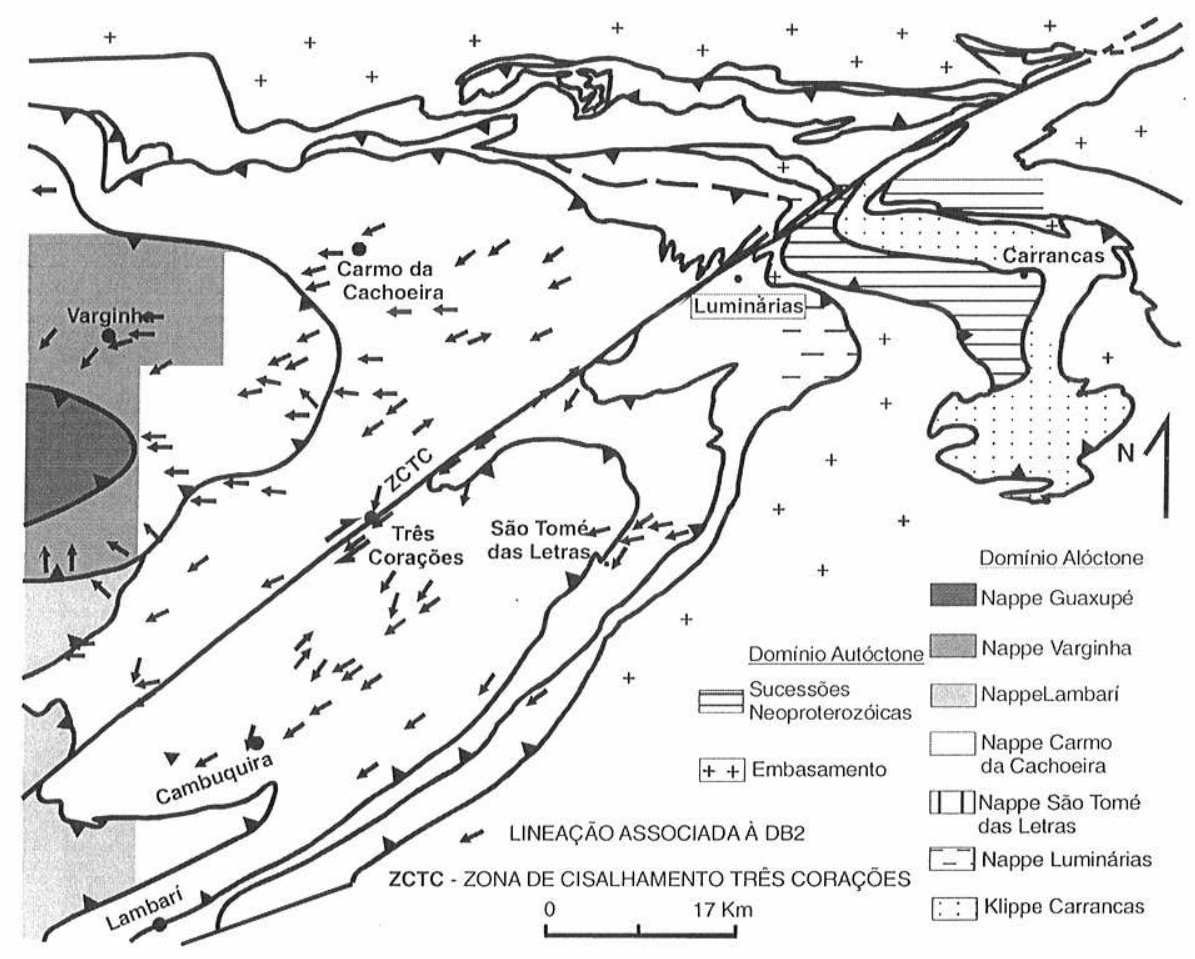

Figura 4 - Mapa estrutural simplificado mostrando as nappes e lineações relacionadas com a fase DB2.

Tabela $2 a$ - Associações minerais caracteristícas das diferentes fácies metamórficas relacionadas aos eventos metamórficos $M_{B}$ e $M_{k}$.

\begin{tabular}{|c|c|c|c|c|}
\hline Evento & Fácie: & Metamórfica & Associações Minerais & Litologia / Unidade \\
\hline \multirow{7}{*}{ MB } & Xisto & Verde Médio & $\mathrm{Bt}+\mathrm{Chl}+\mathrm{Ab}+\mathrm{Qtz}+\mathrm{Ms}$ & metapelito (AL4 e AL5) \\
\hline & & $\begin{array}{l}\text { to Verde } \\
\text { uperior }\end{array}$ & $\begin{array}{r}\mathrm{Grt}+\mathrm{Bt}+\mathrm{Chl}+\mathrm{Ms}+\mathrm{Qtz}+\mathrm{Ab} \text { e Olg+Ep+Rt } \\
\mathrm{Grt}+\mathrm{Cld}+\mathrm{Ms}+\mathrm{Chl}+\mathrm{Qtz}+\mathrm{Ab} \text { e Olg }+\mathrm{R} t+\mathrm{Ep}\end{array}$ & $\begin{array}{l}\text { metapelito (ALI+2 e AL5) } \\
\text { metapelito (AL4) }\end{array}$ \\
\hline & \multirow{2}{*}{\multicolumn{2}{|c|}{ Anfibolito }} & $\mathrm{Grt}+\mathrm{Ky}+\mathrm{St}+\mathrm{Bt}+\mathrm{R} t+\mathrm{MS}+\mathrm{Qtz}+\mathrm{Olg}+\mathrm{Ep}$ & metapelito (AL5 e AL6) \\
\hline & & & $\begin{array}{c}\mathrm{Grt}+\mathrm{Ky}+\mathrm{Ms}+\mathrm{Qtz}+\mathrm{Olg} \\
\mathrm{Grt}+\mathrm{Ky}+\mathrm{Kfs}+\mathrm{Qtz}+\mathrm{Olg}+\mathrm{Bt}+\mathrm{Ms}+\mathrm{Rt} \\
\mathrm{Grt}+\mathrm{Ky}+\mathrm{St}+\mathrm{Ms}+\mathrm{Qtz}+\mathrm{Ep}\end{array}$ & $\begin{array}{c}\text { metapelito (ALI +2) } \\
\text { metapelito (AL6) } \\
\text { quartzito (ALI+2 e AL6) }\end{array}$ \\
\hline & \multirow{3}{*}{ Granulito } & $\begin{array}{l}\text { Nappe Varginha } \\
\text { (base) }\end{array}$ & $\begin{array}{l}\mathrm{Kfs}+\mathrm{Ky}+\mathrm{Grt}+\mathrm{Rt}+\mathrm{Qtz}+\mathrm{Olg} / \mathrm{And}+\mathrm{Bt} \\
\mathrm{Hbl}+\mathrm{Grt}+\mathrm{Cpx}+\mathrm{Qtz}+\mathrm{Pl}+\mathrm{Rt}+\mathrm{Bt}+\mathrm{Spn}\end{array}$ & $\begin{array}{l}\text { metapelito gnáissico (AL6) } \\
\text { rocha metabásica (AL6) }\end{array}$ \\
\hline & & $\begin{array}{l}\text { Nappe Varginha } \\
\text { (topo) }\end{array}$ & $\begin{array}{c}\mathrm{Kfs}+\mathrm{Sil}+\mathrm{Ky}+\mathrm{Grt}+\mathrm{Rt}+\mathrm{Qtz}+\mathrm{OlG} / \mathrm{And}+\mathrm{Bt} \\
\mathrm{Hbl}+\mathrm{Grt}+\mathrm{Cpx}+\mathrm{Opx}+\mathrm{Pl}+\mathrm{Qtz}+\mathrm{Rt}+\mathrm{Bt}\end{array}$ & $\begin{array}{l}\text { metapelito gnáissico (AL6) } \\
\text { rocha metabásica (AL6) }\end{array}$ \\
\hline & & Nappe Guaxupé & $\mathrm{Aug}+\mathrm{Grt}+\mathrm{Hbl}+\mathrm{Bt}+\mathrm{And}+\mathrm{Mc}+\mathrm{Qtz}+\mathrm{Opx}$ & ortognaisse \\
\hline MR & \multicolumn{2}{|c|}{ Anfibolito } & $\mathrm{Sill}+\mathrm{Grt}+\mathrm{St}+\mathrm{Bt}+\mathrm{Qtz}+\mathrm{Olg}$ & metapelito (AL5 e AL6) \\
\hline
\end{tabular}

Tabela $2 b$ - Minerais que marcam a transição, em metapelitos, das fácies metamórficas relacionadas com os eventos MB e MR e as prováveis reações que os formam (segundo Yardley, 1989). Ab-albita; Ads-andesina; Alm-almandina; Di-diopsídio; Bt-biotita; Chlclorita; Cld-cloritóide; Cpx-clinopiroxênio; Ep-epidoto; Grt-granada; Hbl-hornblenda; H2O-água; Ilm-ilmenita; Kfs-K-feldspato; Ky-cianita; Mc-microclina; Ms-muscovita; Olg-oligoclásio; Opx-ortopiroxênio; Pl-plagioclásio; Qtz-quartzo; Rt-rutilo; Sil-sillimanita; St-estaurolita; Spn-titanita (abreviações de minerais segundo Kretz. (1983).

\begin{tabular}{|c|c|c|}
\hline Evento & Limite das Fácies Metamórficas & Prováveis Reações \\
\hline \multirow{6}{*}{ MB } & $\begin{array}{l}\text { Gr-in - transição das fácies xisto verde médio/xisto verde superior em } \\
\text { metapelitos de A3 e A4 }\end{array}$ & $\mathrm{Ch} \mathrm{l}+\mathrm{Ms}=\mathrm{Grt}+\mathrm{Bt}+\mathrm{Qtz}+\mathrm{H} 2 \mathrm{O}(\mathrm{I})$ \\
\hline & $\begin{array}{l}\text { St-in - transição das fácies xisto verde superior/anfibolito em: metapelitos com } \\
\text { Cld de A3 (Almeida, 1992) } \\
\text { metapelitos com Bt de A4 (Oliveira Castro, 1997) }\end{array}$ & $\begin{array}{l}\mathrm{Cld}+\mathrm{Qtz}=\mathrm{St}+\mathrm{Grt}+\mathrm{H} 2 \mathrm{O}(2) \mathrm{ou} \\
\mathrm{Grt}+\mathrm{Ms}+\mathrm{Chl}=\mathrm{St}+\mathrm{Bt}+\mathrm{Qtz}+\mathrm{H} 2 \mathrm{O}\end{array}$ \\
\hline & Ky-in na fácies Anfibolito & $\begin{array}{l}\mathrm{Ms}+\mathrm{St}+\mathrm{Chl}=\mathrm{Bt}+\mathrm{Ky}+\mathrm{Qtz}+\mathrm{H} 2 \mathrm{O}(4) \mathrm{e} \\
\mathrm{St}+\mathrm{Ms}+\mathrm{Qtz}=\mathrm{Grt}+\mathrm{Bt}+\mathrm{Ky}+\mathrm{H} 2 \mathrm{O}\end{array}$ \\
\hline & K-feldspato-in/muscovita-out limite fácies anfibolito/granulito & $\mathrm{Ms}+\mathrm{Qtz}=\mathrm{Kfs}+\mathrm{Ky}+\mathrm{H} 2 \mathrm{O}(6)$ \\
\hline & surgimento do par rutilo-granada & $\mathrm{Il} \mathrm{m}+\mathrm{Ky}+\mathrm{Qtz}=\mathrm{Grt}+\mathrm{Rt}(7)$ \\
\hline & $\begin{array}{l}\text { Sillimanita-in por: aumento de temperatura } \\
\text { diminuição de pressão }\end{array}$ & $\begin{array}{l}\mathrm{Ms}+\mathrm{Qtz}=\mathrm{Sil}+\mathrm{Kfs}+\mathrm{H} 2 \mathrm{O}(8) \text { ou } \mathrm{Ky}=\mathrm{Sil}(9) \\
\mathrm{Grt}(\mathrm{Alm})+\mathrm{Rt}=\mathrm{Ilm}+\mathrm{Sil}+\mathrm{Qtz}(10)\end{array}$ \\
\hline MR & Sillimanita(fibrolita)-in (metapelito) na fácies anfibolito & $\mathrm{St}+\mathrm{Ms}+\mathrm{Qtz}=\mathrm{Grt}+\mathrm{Bt}+\mathrm{Sil}+\mathrm{H} 2 \mathrm{O}(11)$ \\
\hline
\end{tabular}


ou substituindo cianita (9), ou de descompressão, desestabilizando o par granada-rutilo (10). Nestes granulitos, a sillimanita surgiu após a cianita e o K-feldspato que, a princípio, já teriam consumido a muscovita na sua formação. Além disso, a frequiência de cristais de rutilo bordejados por ilmenita e titanita é muito maior no topo da nappe Varginha do que na base. Assim, a hipótese de descompressão seria mais provável para o surgimento da sillimanita que em trajetória P-T-t horária marcaria a temperatura máxima ( $\geq$ $770^{\circ} \mathrm{C}$ ), enquanto os granulitos com cianita indicariam o auge da pressão ( $\mathrm{P} \geq 9$ kbar) para $\mathrm{MB}$.

SEGUNDO EVENTO METAMÓRFICO $\left(M_{R}\right)$ Relacionado à evolução da Faixa Ribeira, com metamorfismo aumentando de norte para sul. A fibrolita (Fig. 3g), característica deste evento, geralmente ocorre ao redor de porfiroblastos de granada, os quais contêm inclusões de cianita e estaurolita, ou bordejando cristais de cianita do evento MB. Assim, fibrolita é interpretada como posterior à associação granada+cianita+estaurolita de $\mathrm{M}_{\mathrm{B}}$, provavelmente formada segundo a reação (11) caracterizando, junto com estaurolita e granada, fácies anfibolito com pressões entre 2 e 6 kbar e temperatura máxima em torno de $670^{\circ} \mathrm{C}$ (Oliveira Castro 1997).

RETROMETAMORFISMO As feições retrometamórficas observadas nos metapelitos são substituições de: biotita por clorita; cianita e sillimanita por muscovita; hornblenda por biotita e actinolita, e plagioclásio bordejado por epidoto, indicando retrometamorfismo em fácies xisto verde. Nos granulitos há crescimento simplectítico de hornblenda e plagioclásio ao redor de granada, indicando processos de descompressão.

Datação do embasamento alóctone Uma amostra de ortognaisse do embasamento alóctone (MR-140, Fig. 2) foi datada através do método U-Pb por diluição isotópica e analisada em espectrômetro de massa por ionização termal (TIMS) no Isotope Geochemistry Laboratory (IGL) da University of Kansas, Estados Unidos. Os procedimentos laboratorias para análise de zircão foram seguidos conforme Krogh (1973) e Parrish (1987). Os grãos de zircão foram concentrados através de líquidos pesados e do separador magnético Franz, resultando em 6 frações magnéticas, de nm (0) até M(4). Foram identificadas apenas duas populações: (1) prisma acicular fino com proporção comprimento/largura 3:1, rosado, transparente, euédrico, com muitas inclusões de minerais escuros, sendo raros os grãos sem inclusões; e (2) prisma acicular, 2: 1 quase $1: 1$, rosa escuro, transparente e euédrico. A primeira população é mais abundante e ocorre em todas as frações, mas os melhores cristais (com menos fraturas e inclusões) somente foram coletados nas frações $n m(0), M(0)$ e $M(1)$. Cada fração foi abradada por 40 minutos sob 4 psi, conforme técnica de Krogh (1982). Seis grãos de zircão foram selecionados manualmente representando seis análises (Tabela 3). A melhor idade foi obtida pelo alinhamento de 5 cristais com o intercepto superior de $2088 \pm 26 \mathrm{Ma}$, interpretada como a época de cristalização do granitóide (Fig. 5). O intercepto inferior, $585 \pm 160 \mathrm{Ma}$, coincide grosseiramente com o período do evento tectonometamórfico que retrabalhou estas rochas. Considerando que os cristais de zircão plotaram próximos ao intercepto superior, conclui-se que estes foram pouco afetados pelo evento termotectônico posterior, não desenvolvendo população neoproterozóica. A idade de 2088土26 Ma é correlacionável com idades do embasamento autóctone estudado por Ávila (2000) e Cherman (2004) na região entre Lavras e São João Del Rei, ao norte da área estudada. Nesta região, granitóides com idades mínimas entre 2.123 e 2.100 Ma (monocristais de zircão analisados pelo método $\mathrm{Pb}-\mathrm{Pb}$ por evaporação) intrudem seqüência vulcano-sedimentar representada pelo Greenstone Belt Barbacena (Pires, 1978).

Relação deformação x metamorfismo Aliando os dados microtectônicos ao mapeamento geológico, pode-se definir a relação entre os eventos metamórficos e as fases deformacionais (Fig. 6e):

$D_{B I}+D_{B 2} x M_{B}$ O primeiro evento metamórfico $\left(\mathrm{M}_{\mathrm{B}}\right)$ que afetou as rochas metassedimentares da MSA apresenta registro de associações minerais de fácies xisto verde cedo $\sin -\mathrm{D}_{\mathrm{B} 1}$, de fácies anfibolito desde cedo sin- $\mathrm{D}_{\mathrm{B} 1}$ até sin- $\mathrm{D}_{\mathrm{B} 2}$ e de fácies granulito sinauge de $\mathrm{D}_{\mathrm{B} 2}$.

A foliação $S_{b 1}$ é definida pela orientação preferencial de muscovita e biotita ou cloritóide, em áreas onde o metamorfismo $M_{B}$ chegou à fácies xisto verde médio. Onde $M_{B}$ alcançou a fácies xisto verde superior também aparece granada crescida sintectonicamente a esta foliação. Cristais de cianita orientados perpendicularmente a $\mathrm{S}_{\mathrm{b} 2}$. com esta foliação contornando-os (Fig. $3 \mathrm{~h})$ ou inclusos em granada, fazendo grande ângulo com $\mathrm{S}_{\mathrm{h},}$, indicam que já ocorria crescimento de cianita, característica de fácies anfibolito em metapelitos, durante $\mathrm{D}_{\mathrm{B} 1}$ a cedo $\sin -\mathrm{D}_{\mathrm{B} 2}$.

Tabela 3 - Dados U-Pb de grãos de zircão da amostra MR-140 (ortognaisse granítico do embasamento alóctone).(a) $n m=$ fração não-magnética; $M=$ fração magnética, números em parênteses indicam a inclinação lateral usada no Separador Magnético Franz a 1,5 A. (b) Concentrações totais de Pb e U corrigidas pelo branco analítico. (c) Pb radiogênico corrigido pelo branco analítico e pelo $\mathrm{Pb}$ não-radiogênico original (seguindo o modelo de Stacey \& Kramers, 1975). A razão ${ }^{206} \mathrm{~Pb}{ }^{204} \mathrm{~Pb}$ corresponde à observada. (d) Idades calculadas com as constantes de decaimento recomendadas por Steiger \& Jäger (1977), incertezas a 2-sigma.

\begin{tabular}{|c|c|c|c|c|c|c|c|c|c|c|c|c|}
\hline \multicolumn{4}{|c|}{ Amostra RD-140 } & \multicolumn{4}{|c|}{ Razões Isotópicas } & \multicolumn{4}{|c|}{ Idades em Ma } & \multirow[b]{3}{*}{$\begin{array}{c}\text { Coeficiente de } \\
\text { Correlação }\end{array}$} \\
\hline \multicolumn{2}{|c|}{ (a) } & \multicolumn{2}{|c|}{ (b) } & \multicolumn{4}{|c|}{ (c) } & \multicolumn{4}{|c|}{ (d) } & \\
\hline Cristal & \begin{tabular}{|l|} 
Peso \\
$(\mathrm{mg})$
\end{tabular} & $\begin{array}{c}\mathrm{Pb} \\
(\mathrm{ppm})\end{array}$ & $\begin{array}{c}\mathrm{U} \\
(\mathrm{ppm})\end{array}$ & $\begin{array}{c}{ }^{206} \mathrm{~Pb} / \\
{ }^{204} \mathrm{~Pb}\end{array}$ & $\begin{array}{l}{ }^{207} \mathrm{~Pb} / \\
{ }^{206} \mathrm{~Pb}\end{array}$ & $\begin{array}{c}{ }^{2077} \mathrm{~Pb} / \\
{ }^{2.35} \mathrm{U}\end{array}$ & $\begin{array}{l}{ }^{206} \mathrm{~Pb} / \\
{ }^{2.38} \mathrm{U}\end{array}$ & \begin{tabular}{|c|}
${ }^{207} \mathrm{~Pb} /$ \\
${ }^{206} \mathrm{~Pb}$
\end{tabular} & $\begin{array}{c}\text { Erro } \\
\text { Ma }\end{array}$ & $\begin{array}{c}{ }^{207} \mathrm{~Pb} / \\
{ }^{2.35} \mathrm{U}\end{array}$ & $\begin{array}{l}{ }^{2066} \mathrm{~Pb} / \\
{ }^{2.38} \mathrm{U}\end{array}$ & \\
\hline $\mathrm{nm}(0)^{*}$ & 0,002 & 98 & 116 & 47,0725 & 0,124722 & 5,83486 & 0,339302 & 2025 & 15 & 1952 & 1883 & 0,991 \\
\hline $\mathrm{nm}(0)_{2}$ & 0,002 & 38 & 84 & 143,57 & 0,127353 & 6,17154 & 0,351465 & 2062 & 7 & 2000 & 1942 & 0,995 \\
\hline $\mathrm{M}(0)$ & 0,003 & 21 & 57 & 279.857 & 0,124601 & 5,46596 & 0,31816 & 2023 & 5 & 1895 & 1781 & 0,995 \\
\hline $\mathrm{M}(0)_{2}$ & 0,007 & 75 & 22 & 156.945 & 0,121834 & 4,8188 & 0,28686 & 1983 & 9 & 1788 & 1626 & 0,996 \\
\hline$M(1)$ & 0,007 & 17 & 46 & 137.008 & 0,124734 & 5,45397 & 0,317122 & 2025 & 11 & 1893 & 1776 & 0,995 \\
\hline$M(2)$ & 0,005 & 42 & 104 & 170.745 & 0,124628 & 5,51596 & 0,321 & 2023 & 7 & 1903 & 1795 & 0,995 \\
\hline
\end{tabular}

(*) cristal não utilizado no cálculo da idade

Intercepto Superior $=2088 \pm 26 \mathrm{Ma} ;$ Intercepto Inferior $=585 \pm 160 \mathrm{Ma}(2$-sigma $) ;$ MSWD $=0,117 ; \mathrm{P}=0.95$ (Modelo $1 ; n=5)$ 


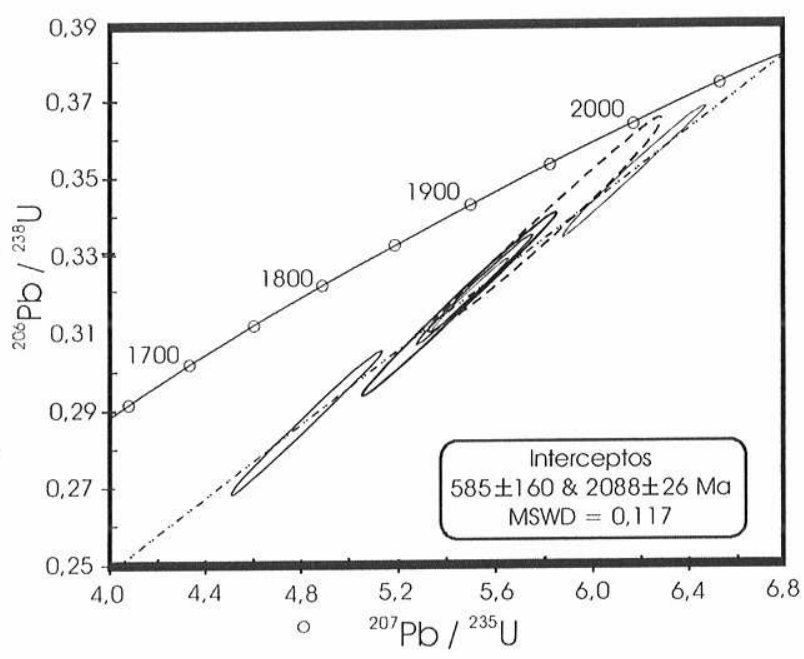

Figura 5 - Diagrama U-Pb com os cristais de zircão da amostra de ortognaisse do embasamento alóctone (MR-140). A regressão não inclui a análise representada pela elipse tracejada. Incertezas a 2-sigma. Idade calculada através da versão 2001 do Isoplot (Ludwig, 2001) utilizando o modelo $1 \mathrm{com}$ probabilidade de $95 \%$.

A foliação $S_{\mathrm{b} 2}$ é definida pela orientação de biotita, cianita, estaurolita, muscovita e fitas de quartzo, em rochas metassedimentares, e clino- e ortopiroxênios e hornblenda em rochas metabásicas. Porfiroblastos de granada cresceram até sinauge de $\mathrm{D}_{\mathrm{B} 2}$, apresentando formas elipsoidais, com o eixo fazendo pequeno ângulo com $\mathrm{S}_{\mathrm{b} 2}$ (Fig. 3i). A sillimanita nos granulitos do topo da nappe Varginha, formada no auge térmico do evento $M_{B}$, ocorre orientada segundo $\mathrm{S}_{\mathrm{b} 2}$ (Fig. $3 \mathrm{j}$ ), freqüentemente apresentando extinção ondulante, indicando crescimento $\sin -\mathrm{D}_{\mathrm{B} 2}$. Entretanto seu surgimento é posterior ao da cianita, pois esta encontra-se inclusa em cristais de granada contornados por $\mathrm{S}_{\mathrm{h} 2}$. Os granulitos da nappe Guaxupé apresentam foliação semelhante à $\mathrm{S}_{\mathrm{b} 2}$ definida pela orientação preferencial de piroxênios, anfibólios, biotita e cristais de granada com forma elipsoidal e eixo maior paralelo à foliação, indicando que também foram metamorfisados $\sin -\mathrm{D}_{\mathrm{B} 2}$.

No domínio autóctone isógradas de granada-in e estaurolitain/cloritóide-out são truncadas pelo empurrão basal da Klippe Carrancas, estrutura da fase $\mathrm{D}_{\mathrm{B} 1}$. No domínio desta klippe, Rocha \& Trouw (2001) identificaram isógrada estaurolita-in/cloritóideout também limitada pela superfície de empurrão $\mathrm{D}_{\mathrm{B} 1}$. Estas relações indicam que desde cedo sin- $\mathrm{D}_{\mathrm{B} 1}$ o metamorfismo $\mathrm{M}_{\mathrm{B}}$ já atuava sobre as rochas da MSA, desde fácies xisto verde médio até fácies anfibolito.

No domínio das nappes Luminárias e São Tomé das Letras isógradas granada-in e estaurolita/cianita-in são truncadas e deslocadas pelos empurrões basais que delimitam estas estruturas da fase $D_{132}$. Já a superfície de empurrão basal da Nappe Carmo da Cachoeira trunca as mesmas isógradas, colocando rochas em fácies anfibolito sobre rochas em fácies xisto verde médio até anfibolito. A isógrada muscovita-out/K-feldspato-in, que representa o limite entre as fácies anfibolito e granulito, coincide com o empurrão basal da Nappe Varginha. No domínio desta nappe ocorre isógrada sillimanita-in com traçado semelhante ao da Nappe Guaxupé. Estas relações indicam que o evento $M_{13}$ continuou atuando até o ápice da fase $D_{132}$, quando atingiu seu auge em fácies granulito.

$D_{R I} x M_{R}$ Registros do evento $\mathrm{M}_{\mathrm{R}}$ são restritos à parte sul da área mapeada, a partir de isógrada sillimanita-in com traçado E-W, que corta as superfícies de empurrão $\mathrm{D}_{\mathrm{B} 2}$ e é deslocada pela Zona de Cisalhamento Três Corações $\left(D_{\mathrm{R} 2}\right)$. Desta isógrada para o sul aumenta a porcentagem de sillimanita em relação à cianita, indicando que o grau metamórfico deste evento também aumenta neste sentido. Este evento é interpretado como sin-tectonico à evolução inicial da Faixa Ribeira, durante fase $D_{\mathrm{RI}}$.

$D_{R 2}$ x RETROMETAMORFISMO Os planos miloníticos $\left(\mathrm{S}_{\mathrm{r} 2}\right)$ desenvolvidos ao longo das zonas de cisalhamento subverticais são definidos pela orientação preferencial de cristais de biotita e clorita e pela concentração de cristais de epidoto, associação característica de fácies xisto verde, equivalente ao retrometamorfismo observado em rochas fora das zonas de cisalhamento, indicando que este provavelmente é contemporâneo à fase $\mathrm{D}_{\mathrm{R} 2}$.

Evolução tectônica brasiliana do sistema de nappes da região de Três Corações A Figura 6 sintetiza e ordena temporalmente as informações apresentadas acerca da evolução estrutural e metamórfica neoproterozóica, envolvendo as rochas metassedimentares da Megassequiência Andrelândia e fatias do seu embasamento, representantes de uma bacia sedimentar em margem passiva, além dos granulitos da Nappe Guaxupé, representantes da raiz de um arco magmático em margem ativa (Campos Neto \& Figueiredo, 1995). Este esquema evolutivo apresenta registros estruturais e metamórficos do início da fase colisional que gerou a Faixa Brasília até o último pulso deformacional relacionado com a evolução da Faixa Ribeira:

1) Em uma etapa inicial $\left(D_{B 1}\right)$ sucessões da Megasseqüiência Andrelândia (AL3 e AL4) são deslocadas em uma fatia tectônica (Klippe Carrancas) de NW para SE e colocadas sobre terreno autóctone composto por sucessões da Megassequiência Andrelândia (AL1+2, AL3 e AL4) e ortognaisses do seu embasamento. Tanto a porção autóctone quanto a alóctone já apresentaram registros de metamorfismo $\left(\mathrm{M}_{13}\right)$, cedo sin- $\mathrm{D}_{\mathrm{B} 1}$ (Fig. 6A).

2) Durante etapa posterior $\left(D_{132}\right)$, porém contínua, ocorreu o deslocamento de outras fatias tectônicas, agora de W/SW para $\mathrm{E}$ / NE, resultando na estruturação do sistema de nappes composto pelas nappes: Luminárias, São Tomé das Letras (Fig. 6B), Carmo da Cachoeira, Lambarí, Varginha e Guaxupé (Fig. 6C). Esta fase deformacional teria ocorrido após o início do evento metamórfico MB até o auge deste evento, como sugerido pela relação entre as superfícies de empurrão DB2 que delimitam as nappes e as isógradas relacionadas a $\mathrm{MB}$.

3) Na terceira etapa $\left(D_{R I}\right)$ as estruturas pré-existentes foram afetadas por dobramento que gerou dobras abertas, com suave assimetria indicando vergência para NW. O evento metamórfico $M_{R}$ ocorreu sin- $D_{R 1}$, com isógradas cortando as estruturas das fases $D_{B 1}$ e $D_{B 2}$, bem como isógradas de $M_{B 3}$ (Fig. 6D).

4) Na última etapa $\left(D_{R 2}\right)$ relacionada à Orogênese Brasiliana registrada na região, estruturas das fases $D_{131}, D_{B 2}$ e $D_{R 1}$ e isógradas dos eventos $M_{B}$ e $M_{R}$ foram afetadas inicialmente por dobras abertas com planos axiais verticais e eixo mergulhando para N-S e posteriormente truncadas e deslocadas por zonas de cisalhamento subverticais destrais com direção NE-SW, associado com retrometamorfismo em fácies xisto verde/anfibolito (Fig. 6E) 

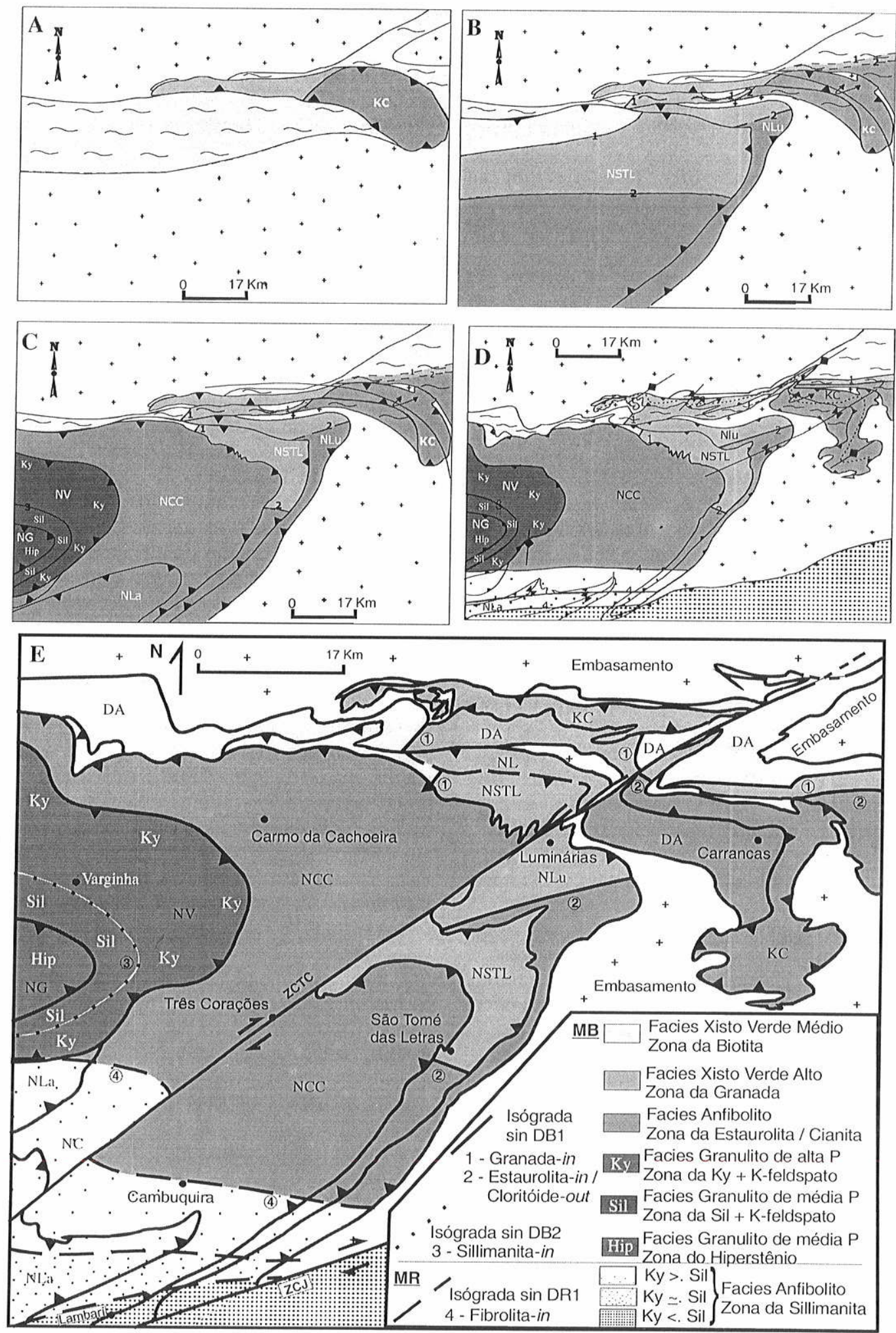

Figura 6 - Mapa metamórfico e esquema simplificado mostrando a evolução estrutural e metamórfica neoproterozóica do sistema de nappes da região de Três Corações e adjacências. DA-Domínio Autóctone; Estrutura DB1: KC-Klippe Carrancas, Estruturas DB2: NG -Nappe Guaxupé, NV - Nappe Varginha, NLa - Nappe Lambarí, NCC - Nappe Carmo da Cachoeira, NSTL - Nappe São Tomé das Letras, NLu - Nappe Luminárias; Estruturas DR2: ZCTC - zona de cisalhamento Três Corações, ZCJ - zona de cisalhamento Jesuânia. Abreviação de minerais: Ky-cianita, Sil-sillimanita, Hip-hiperstênio. Modificado de Ribeiro et al. (1995) e Peternel (2000). 
CORRELAÇÕES DA REGIÃO MAPEADA COM A EXTREMIDADE MERIDIONALDA FAIXA BRASÍLIAE $O$ SEGMENTO CENTRALDAFAIXARIBEIRA Comparando-se a região de interferência entre as faixas Brasília e Ribeira com regiões próximas destas faixas sem interferência, isto é, com a região da Nappe de Passos e com o segmento central da Faixa Ribeira, podese fazer as seguintes correlações:

a) $A$ fase $D_{131}$ pode ser correlacionada a fase D2 descrita na Nappe de Passos; em ambas são registradas superfícies de empurrão com indicação de transporte tectônico de topo para ESE /SE.

b) $\mathrm{Na}$ fase $\mathrm{D}_{132}$ desenvolveu-se um sistema de nappes com transporte tectônico de topo para E / NE que afetou a Klippe Carrancas, estrutura $\mathrm{D}_{\mathrm{B} 1}$, dobrando-a em sinformal fechado com eixo variando de E-W e NW-SE. Apesar de não ser descrita movimentação equivalente na região da Nappe de Passos, esta fase pode ser considerada contínua a fase D2 da Nappe de Passos, sendo a diferença de direção do transporte relacionada com configuração do paleocontinente São Francisco.

c) Tanto o metamorfismo $M_{13}$ quanto o metamorfismo registrado na Nappe de Passos iniciaram-se cedo-sin primeira fase deformacional, seja $\mathrm{D}_{\mathrm{B} 1}$ ou D1, e ambos apresentam associações minerais que indicam pressão relativamente alta. Na Nappe de Passos o metamorfismo atingiu a fácies anfibolito, com auge térmico cedo-D2. No sistema de nappes da região de Três Corações, o metamorfismo $M_{13}$ atingiu fácies granulito, registrado na Nappe Varginha, com auge térmico sin- $\mathrm{D}_{132}$. A correlação entre os registros metamórficos da Faixa Brasília nas regiões de Passos e Três Corações corrobora as correlações feitas acima entre as fases deformacionais destas regiões.

d) A fase $D_{R I}$ registrada na região de Três Corações, que gerou dobras abertas com traço NE-SW, eixos de baixo caimento para WSW e suave assimetria para NNW é correlacionável às fases $D_{R 1}$ e $D_{R 2}$ do segmento central da Faixa Ribeira, (Heilbron et al., 2000) que, mais a sudeste da região de Três Corações, gerou superfícies de empurrão com transporte tectônico de topo para NNW.

e) $O$ metamorfismo $M_{R}$ registrado na região de interferência entre as duas faixas tem características de pressão e temperatura semelhantes às do metamorfismo $\mathrm{M}_{\mathrm{R} 1}$ do segmento central da Faixa Ribeira, apresentando associação mineral de fácies anfibolito de pressão relativamente baixa. Nas duas regiões este evento está associado com as fases deformacionais iniciais da Faixa Ribeira.

f) A última fase deformacional $\left(D_{R 2}\right)$ registrada na área deste trabalho apresenta estruturas que poderiam ser correlacionadas tanto à fase $D_{R 33}$ quanto à fase $D_{R 4}$ de Heilbron et al. (2000) do segmento central da Faixa Ribeira. Como a fase $\mathrm{D}_{\mathrm{R} 2}$ na região de Três Corações está relacionada a episódio compressivo E-W nitidamente posterior a todas as fases deformacionais e eventos metamórficos anteriores, parece mais plausível sua associação com a fase $\mathrm{D}_{\mathrm{R} 4}$ de Heilbron et al (2000) do segmento central da Faixa Ribeira, interpretada da mesma forma e presente em todo segmento. Assim, na região de Três Corações não teria sido encontrado registro da fase $D_{R 3}$ de Heilbron et al (2000) para o segmento central da Faixa Ribeira.

CONCLUSÕES A partir dos dados apresentados neste trabalho, em conjunto com as informações disponíveis na literatura sobre a geologia do sudeste brasileiro, foi possível chegar às seguintes conclusões:

1) Confirma-se a interpretação feita por Trouw et al (1994) que descrevem a região ao sul da borda meridional do Cráton do São Francisco como zona de interferência entre as faixas móveis Brasília e Ribeira, tendo sido possível distinguir as estruturas e as associações minerais metamórficas relacionadas a cada faixa móvel, bem como suas relações de interferência.

2) O evento metamórfico $M_{B}$, relacionado com a Faixa Brasília, atuou do início da fase colisional $\left(D_{B 1}\right)$ entre a paleoplaca Sanfranciscana e a paleoplaca representada pela Nappe de Guaxupé, até auge da colisão $\left(\mathrm{D}_{\mathrm{B} 2}\right)$, quando se formou sillimanita nos granulitos do topo da Nappe Varginha.

3) O surgimento de sillimanita no topo da Nappe Varginha deve estar associado à descompressão sofrida quando esta nappe foi exumada de porções profundas da zona de subducção durante a fase colisional entre o paleocontinente São Francisco e o arco magmático representado pela Nappe Guaxupé. Durante este processo ainda pode ter ocorrido aumento da temperatura por transferência de calor das rochas sobrepostas da Nappe Guaxupé. Assim, os granulitos da Nappe Varginha, com associação mineral incluindo cianita, representariam o auge bárico, enquanto os granulitos com sillimanita representariam o auge térmico do evento $\mathrm{M}_{1 \mathrm{~B}}$.

4) Dois pulsos deformacionais e metamórficos distintos relacionados à Faixa Ribeira estão superpostos às estruturas e metamorfismo da Faixa Brasília na região de Três Corações. O primeiro gerou dobras com vergência para NW e metamorfismo em fácies anfibolito de pressão relativamente baixa e está associado aos empurrões para NNW, registrados no segmento central da Faixa Ribeira. O segundo pulso, gerou dobras abertas com eixo N$\mathrm{S}$ e zonas de cisalhamento destrais NE-SW, estando relacionado a compressão E-W tardia registrada em todo segmento central da Faixa Ribeira.

5) O metamorfismo $M_{R}$, com desenvolvimento de sillimanita nas rochas metassedimentares da Megassequiência Andrelândia, é posterior ao metamorfismo $\mathrm{M}_{\mathrm{B}}$, caracterizado pela cianita nestas rochas.

Agradecimentos À CAPES pela concessão de bolsa de Mestrado e verba do Programa de Apóio a Pesquisa (PROAP); Aos Profs. Drs. André Ribeiro, Fábio Paciullo e Joel Valença pelo apóio ao trabalho; Ao Prof. William Randall Van Schmus (University of Kansas - EUA), pela utilização do IGL (Isotope Geochemistry Laboratory) para datação U-Pb, realizada pela geóloga Renata da Silva Schmitt com apóio de bolsa doutorado sanduíche concedida pelo CNPq (Proc. $\mathrm{n}^{\circ}$ 200978/97.7). Aos revisores da RBG pelas sugestões ao manuscrito.

\section{Referências}

Almeida F.F.M.de \& Hasui Y. (Eds.) 1984. O Pré-Cambriano do Brasil. Editora Edgard Blucher, São Paulo, 378 pp.

Almeida J.C.H. 1992. Mapeamento geológico da Folha Luminárias MG (1:50.000), ênfase na análise estrutural dos metassedimentos do Ciclo Andrelândia. Dissertação de Mestrado, Instituto de Geociências, Universidade Federal do Rio de Janeiro, 102 p.

Ávila C.A. 2000. Geologia, Petrologia e Geocronologia de corpos plutônicos paleoproterozóicos da borda meridional do Cráton do 
São Francisco, São João Del Rei, M.G. Tese de Doutorado, IG/ UFRJ, $381 \mathrm{p}$.

Bittar S.M.B. 1989. Mapeamento geológico-estrutural da Folha Caxambú e da parte sul da Folha Luminárias. Dissertação de Mestrado, IG/ UFRJ, $226 \mathrm{p}$.

Campos Neto M.C. \& Caby R. 1999. Neoproterozoic high-pressure metamorphism and tectonic constraint from nappe system south of the São Francisco Craton, southeast Brazil. Prec. Res., 97:3-26

Campos Neto M.C. \& Figueiredo M.C.H. 1995. The Rio Doce Orogeny, southeastern Brazil. J. South Am. Earth Science, 8:143-162

Cherman A.F. 2004. Geologia, petrologia e geocronologia de Ortognaisses Paleoproterozóicos da borda meridional do Cráton do São Francisco, na região entre Itumirim e Nazareno, Minas Gerais. Tese de Doutorado, IG/UFRJ, 259 p.

Dardenne M.A. 2000. The Brasília Fold Belt. In: U.G. Cordani, E.J. Milani, A. Thomaz Filho, D.A. Campos (eds.) Tectonic Evolution of South America. Rio de Janeiro 31 $3{ }^{\text {st }}$ International Geological Congress, pp.: 231-263

Fuck R.A., Pimentel M.M., Silva J.H.D. 1994. Compartimentação tectônica na porção oriental da Província Tocantins. In: SBG, Cong. Bras. Geol., 38, Anais, 1:215-216

Heilbron M., Mohriak W., Valeriano C.M., Milani E., Almeida J.C.H. ,Tupinambá M. 2000. From Collision to Extension: The Roots of the Southeastern Continental Margim of Brazil. In: W.U. Mohriak \& M. Talwani (eds) Atlantic rifts and continental margins. Am. Geoph. Union, Geophysical Monographss, Washington, Serie 115, p. 1-32

Kretz R. 1983. Symbols for rock-forming minerals. Am. Mineral., 68:277279

Krogh T.E. 1973. A low contamination method of hydrothermal decomposition of zircon and extraction of $\mathrm{U}$ and $\mathrm{Pb}$ for isotopic age determinations. Geoch. Cosmoch. Acta, 37:485-494

Krogh T.E. 1982. Improved accuracy of U-Pb zircon ages by the creation of more concordant systems using an air abrasion technique. Geoch. Cosmoch. Acta, 46:637-649

Ludwig K.L. 2001. Users manual for Isoplot/Ex v. 2.3. A geochronological toolkit for Microsoft Excel. Berkeley Geochronological Center Special Publication n. 1a, Berkeley, California, $57 \mathrm{pp}$.

Machado N., Valladares C., Heilbron M., Valeriano C. 1996. U-Pb geochronology of the central Ribeira belt (Brazil) and implications for the evolution of the Brazilian Orogeny. Prec. Res., 79:347-361

Marini O.J., Fuck R.A., Danni J.C.M., Dardenne M.A., Loguércio S.O., Ramalho R. 1984. As faixas de dobramento Brasília, Uruaçu, Paraguai-Araguaia e o Maciço Mediano de Goiás. In: C. Schobbenhaus, D.A. Campos, G.R. Derze, H.E. Asmus (eds.), Geologia do Brasil, DNPM, Brasília, pp.: 251-303

-Oliveira Castro E.M. 1997. Mapeamento geológico-estrutural e petrografia das sucessões pré-cambrianas da área de Lambarí, Minas Gerais. Dissertação de Mestrado, IG/UFRJ, 103 p.

Paciullo F.V.P. 1997. A Sequência Deposicional Andrelândia. Tese de Doutorado, IG/UFRJ, 248 p.

Paciullo F.V.P., Ribeiro A., Andreis R.R., Trouw R.A.J. 2000. The Andrelândia basin, a Neoproterozoic intraplate continental margin, southern Brasília. Rev.Bras.Geoc., 30:200-202.

Paciullo F.V.P., Trouw R.A.J., Ribeiro A. 2003. Geologia da Folha Andrelândia. In: A.C. Pedrosa-Soares, C.M. Noce, R.A.J Trouw,
M. Heilbron (orgs.).Geologia e Recursos Minerais do Sudeste Mineiro, Projeto Sul de Minas, 1:84-120.

Parrish R.R. 1987. An improved micro-capsule for zircon dissolution in U-Pb geochronology. Isotope Geoscience, 66:99-102

Passchier C. W., 1986. Flow in natural shear zones: the consequences of spinning flow regimes. Earth Planet. Sci. Letters 77:70-80

Peternel R. 2000. Evolução estrutural e metamórfica de um sistema de nappes na região de Três Corações, sul de Minas Gerais. Dissertação de Mestrado, IG/UFRJ, 120 p.

Pimentel M.M., Heaman L., Fuck R.A., Marini O.J. 1992. Idade do metariolito da Sequência Maratá, Grupo Araxá, Goiás: estudo geocronológico pelos métodos U-Pb em zircão, Rb-Sr e Sm-Nd. Anais da Academia Brasileira de Ciências, 64:19-28

Pires F.R.M. 1978. The Archean Barbacena Greenstone Belt in its typical development and the itabirite distribuition at the Lafaiete District. Anais Acad. Brasil. Ciências. 50:599-600

Ribeiro A., Andreis R.R., Trouw R.A.J., Paciullo F.V.P., Valença J.G. 1995. Evolução das bacias proterozóicas e o termo-tectonismo brasiliano na margem sul do Cráton do São Francisco. Rev.Bras. Geoc., 25:235-248

Ribeiro A., Paciullo F.V.P., Andreis R.R., Trouw R.A.J., Heilbron M. 1990. Evolução policíclica proterozóica no sul do Cráton do São Francisco: análise da região de São João del Rei e Andrelândia, MG. In: SBG, Congr. Bras. Geol, 36, Anciis, 6:2605-2614

Rocha F.P. \& Trouw R.A.J. 2001. Estudo microtectônico da Sequência Metassedimentar Andrelândia na Serra do Pombeiro, Itutinga, sul de Minas Gerais. In: SBG, Simp. Geol. Sudeste, 7, Boletim de Resumos p. 23

Schmitt R.S. 2001. A Orogernia Búzios - Um evento tectono-metamórfico cambro-ordoviciano caracterizado no Domínio Tectônico de Cabo Frio, Faixa Ribeira, sudeste do Brasil. Tese de Doutorado, IG/ UFRJ, 273 p.

Simões L.S.A. 1995 Evolução tectono-metamórfica da Nappe de Passsos, sudoeste de Minas Gerais. Tese de Doutorado, IG/USP, 149 p.

Söllner F. \& Trouw R.J.A. 1997. The Andrelândia depositional Cycle (Minas Gerais/Brazil), a Post-Transamazonic Sequence South of the São Francisco Craton: Evidence from U-Pb Dating on Zircons of a Metasediment. J. South Am. Earth Sci., 10:21-28

Stacey J.S. \& Kramers J.D. 1975. Approximation of teretrial lead isotope by a two-stage model. Earth Planet. Sci. Lett., 26:207-221

Steiger R.H. \& Jäger E. 1977. Subcommission on Geochonology: convention on the use of decay constants in geo- cosmochronology. Earth Planet. Sci. Lett., 36:359-362.

Trouw R.A.J., Heilbron M., Ribeiro A., Paciullo F.V.P., Valeriano C.M., Almeida J.C.H., Tupinambá M., Andreis R.R. 2000. The Central Segment of the Ribeira Belt. In: U.G Cordani, E.J. Milani, A. Thomaz Filho, D.A. Campos (eds.) Tectonic Evolution of South America. Rio de Janeiro $31^{\text {st }}$ International Geological Congress, pp. 287-310

Trouw R.A.J. \& Oliveira Castro E.M. 1996. Significado tectônico de granulitos brasilianos de alta pressão no sul de Minas Gerais. In: SBG, Cong. Bras. Geol., 39, Anais, 6:145-148

Trouw R.A.J., Paciullo F.V.P., Ribeiro A. 1994. A Faixa Alto Rio Grande reinterpretada como zona de interferência entre a Faixa Brasília e a Faixa Ribeira. In: SBG, Cong. Bras. Geol., 38, Res. Exp., 3:234-235

Trouw R.A.J. \& Pankhrust R.J. 1993. Idades radiométricas ao sul do Cráton do São Francisco: Folha Barbacena, Minas Gerais. In : SBG, Simp. Cráton do São Francisco, 2, Anais, p. 260-262 
Tupinambá M., Teixeira W., Heilbron M. 1998. The Pan African/Brasiliano Arc-related Magmatism at the Costeiro Domain of the Ribeira belt, Southeastern Brazil, In: SBG, Intern. Conf. Prec. Craton Tectonics, 14, Abstract, p. 12-14.

Valeriano C.M. 1999. A Faixa Brasília meridional com ênfase no segmento da represa de Furnas: estado atual do conhecimento e modelos de evolução tectônica. Tese de Livre Docência, Faculdade de Geologia, UERJ, 93 p.

Valeriano C.M., Simões L.S.A., Heilbron M. 1993. Compartimentação tectônica da porção meridional da Faixa Brasília, SW de Minas Gerais: implicações sobre a definição do limite regional do Cráton do São Francisco. In: SBG/SGM/CNPq, Simpósio sobre o Cráton do São Francisco. Anais, p. 275-276

Yardley B.W.D (Ed.) 1989. An introduction to Metamorphic Petrology. Longman Scientific \& Technical, Essex, 248 pp.

Manuscrito A-1457

Recebido em 05 de agosto de 2003

Revisão dos autores em 08 de setembro de 2005 Revisão aceita em 15 de setembro de 2005 